\title{
Safe And Efficient Collection of Cytokine-Mobilized Peripheral Blood Cells From Cynomolgus Monkeys (Macaca fascicularis) with Human Newborn-Equivalent Body Weights
}

\author{
Naohide AGEYAMA ${ }^{1,2)}$, Yutaka HANAZONO ${ }^{3)}$, Hiroaki SHIBATA ${ }^{1,3)}$, Fumiko ONO2), \\ Hiromi OGAWA'2), Takeyuki NAGASHIMA4), Yasuji UEDA ${ }^{4)}$, Yasuhiro YOSHIKAWA5), \\ Mamoru HASEGAWA4), Keiya OZAWA ${ }^{3)}$, and Keiji TERAO'1)
}

\begin{abstract}
1)Tsukuba Primate Research Center, National Institute of Biomedical Innovation, Ibaraki 305-0843, ${ }^{2)}$ Corporation for Production and Research of Laboratory Primates, Ibaraki 305-0843, 3)Center for Molecular Medicine, Jichi Medical School, Tochigi 329-0498, 4)DNAVEC Corporation, Ibaraki 305-0856, 5)Department of Biomedical Science, Graduate School of Agriculture and Life Science, University of Tokyo, Tokyo 113-8657, Japan
\end{abstract}

\begin{abstract}
Hematopoietic stem cells in bone marrow can be mobilized into peripheral blood by cytokine administration. Cytokine-mobilized peripheral blood stem cells are of great use in clinical applications. We previously established a modified procedure for the collection of cytokine-mobilized peripheral blood cells from rhesus monkeys (Macaca mulata) using a commercially available apparatus originally developed for human subjects. In this study, we examined the efficacy and safety of this method with even smaller macaques, cynomolgus monkeys (Macaca fascicularis), which are equivalent to human newborns in body weight (mean $=3.3 \mathrm{~kg}$ ). Using the manufacturer's unmodified protocol $(n=6)$, one monkey died of cardiac failure and three developed severe anemia. In contrast, using our modified procedure $(n=6)$, no such complication was observed in any animal. In addition, the harvested nuclear cell, mononuclear cell and $\mathrm{CD} 34^{+}$cell counts were significantly higher with the modified method. The modified method should allow safe and efficient collection of cytokine-mobilized peripheral blood cells from non-human primates as small as human newborns in a non-invasive manner.
\end{abstract}

Key words: cynomolgus monkey, cytokine mobilization, leukapheresis, peripheral blood stem cell

\section{Introduction}

Although hematopoietic stem cells (HSCs) usually reside in the bone marrow, they can be mobilized into the peripheral blood by the administration of cytokines such as granulocyte colony-stimulating factor (G-CSF) [24]. Cytokine-mobilized peripheral blood stem cells are widely used for autologous and allogeneic trans-

(Received 23 April 2005 / Accepted 21 July 2005)

Address corresponding: Y. Hanazono, Division of Regenerative Medicine, Center for Molecular Medicine, Jichi Medical School, 3311-1 Yakushiji, Minamikawachi, Tochigi 329-0498, Japan 
Table 1. Hematological analysis of cynomolgus monkeys after cytokine treatment

\begin{tabular}{|c|c|c|c|c|c|c|c|c|}
\hline \multirow[b]{2}{*}{ Animals } & \multirow[b]{2}{*}{ Sex } & \multirow[b]{2}{*}{$\begin{array}{c}\text { Age } \\
\text { (years) }\end{array}$} & \multirow{2}{*}{$\begin{array}{c}\text { Body } \\
\text { weight } \\
(\mathrm{kg})\end{array}$} & \multicolumn{5}{|c|}{ After cytokine treatment } \\
\hline & & & & $\begin{array}{l}\text { White blood } \\
\text { cells }\left(10^{2} / \mu \mathrm{l}\right)\end{array}$ & $\begin{array}{c}\text { Red blood } \\
\text { cells }\left(10^{4} / \mu \mathrm{l}\right)\end{array}$ & $\begin{array}{l}\text { Hemoglobin } \\
(\mathrm{g} / \mathrm{dl})\end{array}$ & $\begin{array}{c}\text { Hematocrit } \\
(\%)\end{array}$ & $\begin{array}{c}\text { Platelets } \\
\left(10^{4} / \mu \mathrm{l}\right)\end{array}$ \\
\hline \multicolumn{9}{|c|}{ Unmodified procedure } \\
\hline 292049 & Male & 6 & 4.6 & 680 & 632 & 12.0 & 41.4 & 36.1 \\
\hline 293051 & Female & 6 & 2.5 & 1091 & 535 & 10.7 & 39.0 & 35.7 \\
\hline 292079 & Female & 7 & 3.2 & 514 & 480 & 11.6 & 36.5 & 35.8 \\
\hline 292238 & Female & 7 & 3.2 & 548 & 653 & 13.4 & 44.4 & 30.0 \\
\hline 394029 & Female & 5 & 3.2 & 355 & 590 & 11.7 & 42.3 & 42.4 \\
\hline 296116 & Male & 3 & 3.1 & 361 & 583 & 12.0 & 43.8 & 26.6 \\
\hline Average & & 5.7 & 3.3 & 592 & 579 & 11.9 & 41.2 & 34.4 \\
\hline \multicolumn{9}{|c|}{ Modified procedure } \\
\hline 001046 & Female & 3 & 3.5 & 872 & 484 & 12.4 & 38.9 & 43.7 \\
\hline 001045 & Male & 3 & 3.3 & 519 & 415 & 9.7 & 33.4 & 44.2 \\
\hline 001049 & Male & 3 & 3.5 & 434 & 501 & 12.3 & 38.7 & 43.8 \\
\hline 001053 & Male & 3 & 2.6 & 802 & 456 & 10.3 & 35.1 & 57.7 \\
\hline 001047 & Male & 4 & 3.3 & 805 & 438 & 11.1 & 35.3 & 40.4 \\
\hline 398042 & Male & 5 & 3.8 & 887 & 521 & 11.9 & 36.8 & 38.4 \\
\hline Average & & 3.5 & 3.3 & 720 & 469 & 11.3 & 36.3 & 44.7 \\
\hline
\end{tabular}

plantation therapies to treat hematological malignancies such as leukemia and lymphoma $[16,17]$. The cells have also been intensively studied as a donor source of stem cells for gene and cell therapies [11, 20, 30]. An efficient method for collecting cytokine-mobilized peripheral blood cells in monkeys would facilitate such studies in a clinically relevant manner.

The procedure for collecting peripheral blood cells from living animals is referred to as leukapheresis: peripheral blood is withdrawn, nuclear cells are removed, and the rest of the blood is returned [7]. Automatic instruments for this procedure are commercially available [23, 27]. The removed cells are then enriched for a stem cell fraction such as $\mathrm{CD} 34^{+}$or $\mathrm{AC} 33^{+}$cells for clinical applications [5, 29]. Although leukapheresis is widely conducted for human adults, it is difficult to apply to regular experimental macaque monkeys because of their small size. Generally speaking, the procedures involved preclude the application of leukapheresis to animals weighing less than $10 \mathrm{~kg}$ in body weight [18].

We and others have previously reported leukapheresis procedures for non-human primates with body weights of less than $10 \mathrm{~kg}$ using rhesus monkeys (Macaca mulata, average $7 \mathrm{~kg}$ ) [3,9]. In such small animals, acute cardiac failure due to the relatively large extracorporeal blood flow is a critical adverse event which can occur during leukapheresis. To avoid this, we modified the procedure by reducing the extracorporeal blood volume as much as possible and adjusting the withdrawal speed frequently in response to the results of real-time monitoring of hemoglobin ( $\mathrm{Hb})$ and hematocrit $(\mathrm{Ht})$ values [3]. In this study, we examined the efficacy and safety of our procedure using even smaller non-human primates, cynomolgus monkeys (Macaca fascicularis, average $3.3 \mathrm{~kg}$ ), which have body weights equivalent to human newborns.

\section{Materials and Methods}

\section{Animals}

Twelve cynomolgus monkeys (Macaca fascicularis) (3-7 years old, 2.5-4.6 kg) bred at the Tsukuba Primate Research Center (Ibaraki, Japan) were enrolled in this study (Table 1). Animals were free of intestinal parasites, herpes-B, simian type-D retrovirus and simian varicella virus. All monkeys were housed indoors at $23-27^{\circ} \mathrm{C}$ and $50-70 \%$ humidity with 12 air changes per hour and a 12-h/12-h light/dark cycle. Animals were individually housed in stainless steel cages and fed $70 \mathrm{~g}$ of commercial monkey chow (Type AS; Oriental Yeast, Chiba, Japan) and $200 \mathrm{~g}$ of fruit daily. All monkeys were healthy as assessed by annual examinations. This 


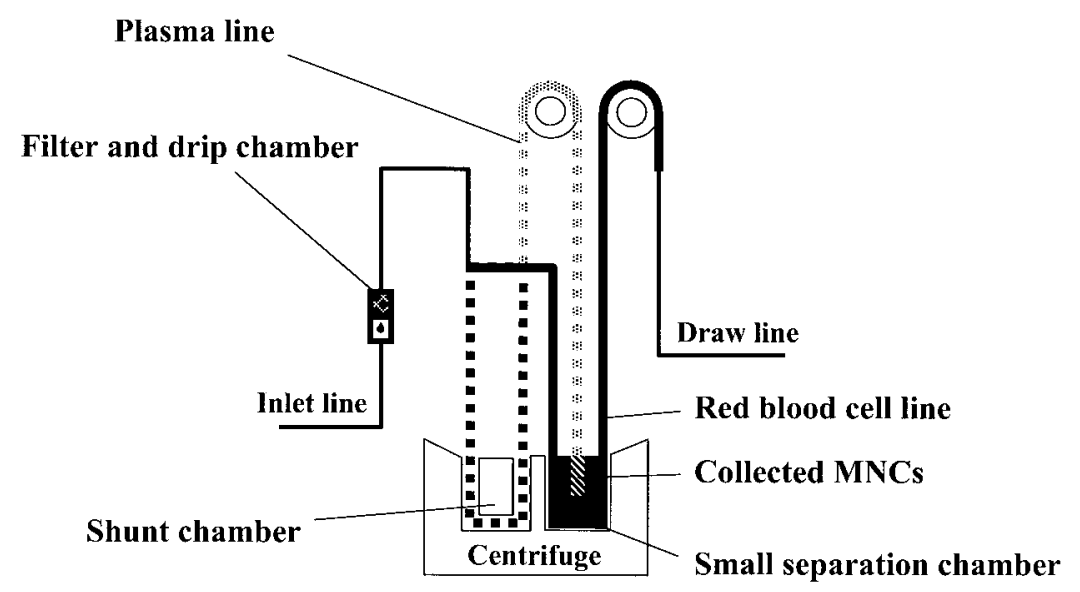

..... Removed extracorporeal plasma lines

Fig. 1. Diagram of the apheresis kit after the modifications. In the modified system, a small separation chamber (S25A) was installed in the standard apheresis kit and the extracorporeal blood lines were shortened to reduce the extracorporeal blood volume from 130 to $70 \mathrm{ml}$. MNCs, mononuclear cells.

study was conducted according to the Rules for Animal Care and Management of the Tsukuba Primate Research Center [12] and the Guiding Principles for Animal Experiments Using Non-human Primates formulated by the Primate Society of Japan [21]. This study was approved by the Animal Welfare and Animal Care Committee of the National Institute of Infectious Diseases.

\section{Apparatus}

A CS3000 blood separator (Baxter, Deerfield, IL, USA) was used as described previously [3]. Briefly, a standard apheresis kit was installed in the CS3000 blood separator. The smallest separation chamber (S25A) in the kit was used. To reduce the extracorporeal blood volume, the plasma line of the standard apheresis kit was cut away and the red blood cell (RBC) line was directly connected to the inlet line using a polypropylene tube connector (Iuchi, Osaka, Japan) under sterile conditions, bypassing the shunt chamber (Fig. 1). In addition, the regular inlet and draw lines were replaced with lines shorter in length and smaller in diameter (extension tube, $70 \mathrm{~cm}, 1.4 \mathrm{ml}, 2.5 \mathrm{~mm}$ diameter; TOP, Tokyo, Japan) to further reduce the extracorporeal blood volume.

\section{Preparative regimen}

During the three weeks preceding leukapheresis, a total of 60-90 ml of autologous blood was obtained from each monkey as described previously [6]. The collected autologous blood was supplemented with acid citrate dextrose (ACD) and stored at $4{ }^{\circ} \mathrm{C}$ prior to use. Recombinant human (rh) stem cell factor ( $\mathrm{SCF}, 50 \mu \mathrm{g} /$ kg; Amgen, Thousand Oaks, CA, USA) and rhG-CSF (50 $\mu \mathrm{g} / \mathrm{kg}$; Chugai, Tokyo, Japan) were administered to animals subcutaneously daily during the 5 days preceding leukaphersis [9]. On the day of leukapheresis, the right or left femoral artery was cannulated using a 5-Fr polyurethane catheter (Anthron PU; Toray, Tokyo, Japan). The saphenous vein was also catheterized with a 19-gauge intracatheter (Terumo, Tokyo, Japan). This cannulation was performed under general anesthesia with the administration of ketamine hydrochloride (Ketalar; Sankyo, Tokyo, Japan).

\section{Leukapheresis}

All leukapheresis procedures were performed under general anesthesia with endotracheal intubation (Fig. 2). Vital signs were monitored with electrocardiography, blood pressure, oxygen saturation and respiration. Animals received a dose of $100 \mathrm{U} / \mathrm{kg}$ heparin (Aventis Pharma, Frankfurt, Germany) just before the initiation of leukapheresis. The plasma flowed directly into the inlet line bypassing the shunt chamber (Fig. 1). The inlet line 


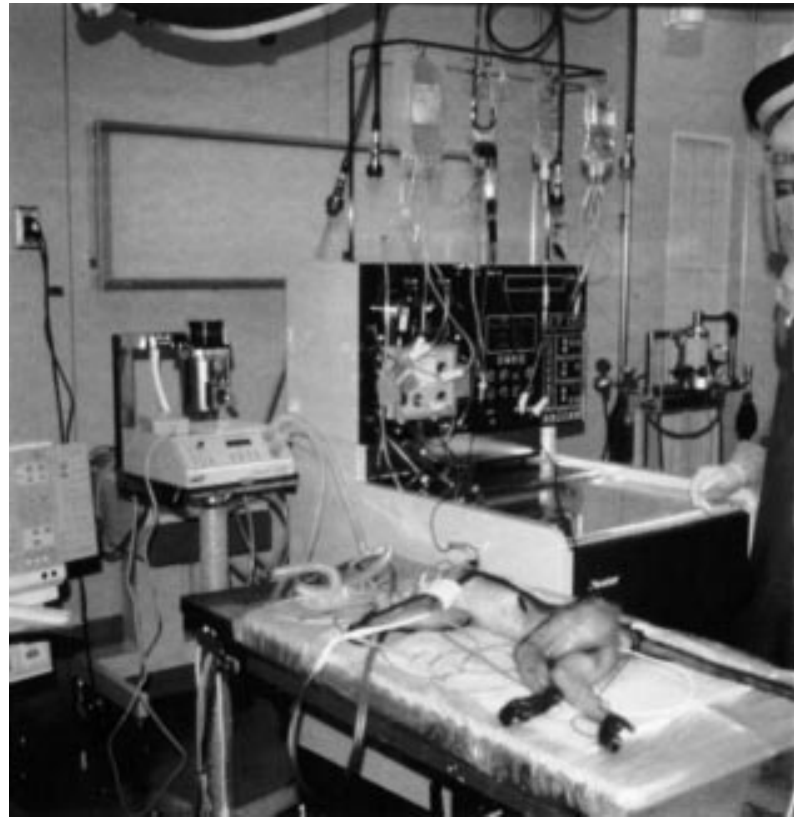

Fig. 2. Leukapheresis procedure. Cynomolgus monkeys were intubated and all procedures were performed under general anesthesia with monitoring of vital signs. The body weights ( $3.3 \mathrm{~kg}$ on average, see Table 1$)$ were similar to those of human newborns.

was connected to an intracatheter placed in the saphenous vein of the animal. The draw line was connected to a catheter in the femoral artery just before starting the procedure. The apheresis kit was filled with the autologous blood collected as described above.

After the leukapheresis was completed, the blood remaining in the apheresis kit was recovered and either used to fill another apheresis kit or returned into the animal. Immediately after the leukapheresis, animals were given an appropriate dose $(10 \mathrm{mg}$ per $1,000 \mathrm{U}$ heparin) of protamine sulfate (Aventis Pharma) to neutralize heparin. Animals also received a course of 0.5 $\mathrm{mg} / \mathrm{kg}$ butorphanol tartrate (Bristol-Myers Squibb, New York, NY, USA) intramuscularly for 3 days to alleviate any post-operative pain.

\section{Analysis of leukapheresis products}

The product obtained during leukapheresis was collected in the S25A separation chamber. The product (40-45 ml) was mixed with $7 \mathrm{ml}$ of ACD. The recovered RBCs, white blood cells (WBCs), mononuclear cells and platelets were enumerated with a Sysmex K4500 instrument (Toa-iyoudenshi, Kobe, Japan). Hb and $\mathrm{Ht}$ values were also examined with this instrument. Although the instrument was originally developed for human blood samples, we have confirmed that it works properly for monkey blood samples. Blood cells were collected after centrifugation at 1,200 rpm for $10 \mathrm{~min}$ and suspended in the ACK buffer (Biosource, Camarillo, CA, USA) for the lysis of RBCs. CD34+ cells were isolated with immunomagnetic beads conjugated to a monoclonal antibody clone 561 (Dynal, Lake Success, NY, USA) that reacts to both human and cynomolgus CD34 [26, 33]. The harvested $\mathrm{CD}_{4} 4^{+}$cells were counted. CD34 is a clinically-relevant cell-surface marker of HSCs, and $\mathrm{CD} 34^{+}$cell transplantation is widely performed as HSC transplantation in patients with cancer or other disorders [5, 19].

\section{Results}

We examined the safety and efficacy of leukapheresis using the manufacturer's protocol $(n=6)$ and our modified version ( $\mathrm{n}=6$ ) in cynomolgus monkeys (Fig. 2). In both groups, we administered G-CSF and SCF to monkeys for 5 days to mobilize HSCs into the peripheral blood. The administration resulted in an increase in peripheral WBC counts to 66,000 cells/ $\mu 1$ on average (Table 1), and was not associated with any adverse effect such as fever or anorexia. There was no significant difference in the increase in the peripheral WBC counts after cytokine treatment between the unmodified and modified procedure groups. In the modified protocol, a small separation chamber (S25A) was installed instead of the regular one in the blood separator, and the extracorporeal blood lines in the standard apheresis kit were shortened $[3,9,22]$. As a result, the extracorporeal blood volume was reduced from 130 to $70 \mathrm{ml}$ (Fig. 1). In both groups, blood was processed at a rate of $10-12 \mathrm{ml} / \mathrm{min}$ and the total processed volume was two to three times the estimated total blood volume [4] of each animal (Table 2). In the modified protocol, every time the processed blood volume increased by $50 \mathrm{ml} / \mathrm{kg}$, a $1-\mathrm{ml}$ blood sample was collected via the draw line, and $\mathrm{Hb}$ and $\mathrm{Ht}$ values were examined throughout the procedure to adjust the plasma pump speed [14]. The plasma pump speed was increased when $\mathrm{Hb}$ and $\mathrm{Ht}$ values decreased. Conversely, it was decreased when $\mathrm{Hb}$ and $\mathrm{Ht}$ values increased. In addition, when $\mathrm{Hb}$ and $\mathrm{Ht}$ values increased, normal saline 
Table 2. Leukapheresis procedures

\begin{tabular}{ccccc}
\hline \multirow{2}{*}{ Animals } & $\begin{array}{c}\text { Estimated total blood } \\
\text { volume }(\mathrm{ml})^{*}\end{array}$ & \multicolumn{2}{c}{ Processed blood } & Complications \\
\cline { 3 - 4 } & & Total volume $(\mathrm{ml})$ & $\mathrm{ml} / \mathrm{kg}$ & \\
\hline $\begin{array}{c}\text { Unmodified procedure } \\
292049\end{array}$ & 293 & 600 & 130 & None \\
293051 & 217 & 600 & 240 & Severe anemia \\
292079 & 231 & 400 & 125 & Severe anemia \\
& & & & Died of cardiac failure \\
292238 & 231 & 600 & 188 & None \\
394029 & 231 & 700 & 219 & Severe anemia \\
296116 & 227 & 600 & 194 & None \\
\hline Average & 238 & 583 & 183 & \\
\hline Modified procedure & & & & None \\
001046 & 237 & 750 & 214 & None \\
001045 & 236 & 600 & 182 & None \\
001049 & 244 & 800 & 229 & None \\
001053 & 205 & 500 & 192 & None \\
001047 & 236 & 600 & 182 & None \\
398042 & 258 & 700 & 183 & 197 \\
\hline Average & 236 & 658 & & \\
\hline
\end{tabular}

*The total blood volume was estimated with the following formula [4]. For males, $($ Total blood volume, $\mathrm{ml})=44.07$ $\times($ Body weight, $\mathrm{kg})+90.25$. For females, $($ Total blood volume, $\mathrm{ml})=19.95 \times($ Body weight, $\mathrm{kg})+167.24$.

was infused via the inlet line for volume replacement.

After the completion of the unmodified procedure $(n=6)$, one animal died of acute cardiac failure and three animals developed severe anemia $(\mathrm{Hb}<8.0 \mathrm{~g} / \mathrm{dl}$, Fig. 3). In contrast, none of the animals that underwent the modified procedure $(n=6)$ developed cardiac failure or severe anemia (Table 2). The $\mathrm{Hb}$ and $\mathrm{Ht}$ values were significantly better preserved during the modified procedure (Fig. 3). In addition, the numbers of harvested nuclear cells, mononuclear cells, and $\mathrm{CD} 34^{+}$cells were significantly increased with the modified procedure compared to the unmodified one (Fig. 4).

The leukapheresis products were contaminated with considerable amounts of RBCs and platelets, when the apparatus was operated in automatic mode under the unmodified protocol. In the modified version, we performed manual adjustment of the plasma pump speed in response to the results of the real-time monitoring of $\mathrm{Hb}$ and $\mathrm{Ht}$ values during the leukapheresis as described above, and successfully reduced the contamination (data not shown). The reduction in contaminated RBCs also contributed to the amelioration of anemia after leukapheresis in the modified procedure group. No microbial contamination was detected in cultures of the leukapheresis products from the unmodified or modified procedures.

\section{Discussion}

In this paper, we reported leukapheresis in cynomolgus monkeys. Our modified protocol significantly improved mononuclear and $\mathrm{CD} 34^{+}$cell harvest compared to the manufacturer's protocol. Under our modified procedure, we routinely collected $5 \times 10^{6}$ $\mathrm{CD} 34^{+}$cells per $\mathrm{kg}$, which is equivalent to numbers in human trials published in the literature [13, 25, 28, 31]. Thus, with our modified protocol, it is possible to collect sufficient numbers of $\mathrm{CD} 34^{+}$stem cells for various applications including transplantation experiments in monkeys. In fact, we achieved successful hematopoietic reconstitution in myeloablated cynomolgus monkeys after the autologous transplantation of $\mathrm{CD} 34^{+}$ cells obtained with this procedure [2]. Of note, this procedure can be safely and effectively applied to monkeys with small body weights $(2.6-3.8 \mathrm{~kg})$, equivalent to those of human newborns. Although numerous clinical trials have demonstrated the safety and effectiveness 
A

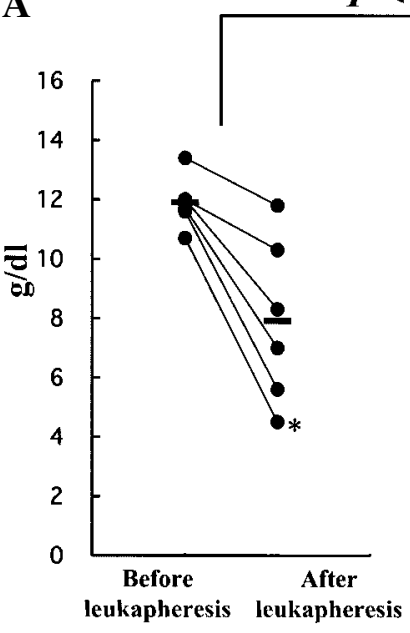

Unmodified procedure
$P<0.05$

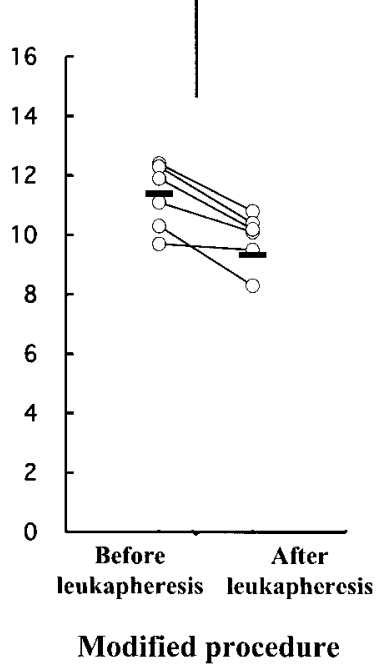

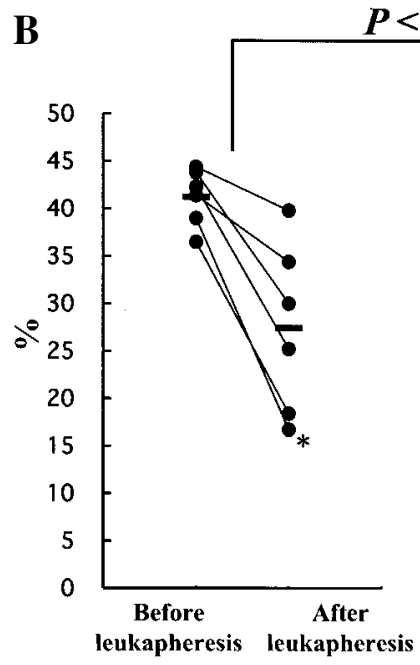

Unmodified procedure
$P<0.05$

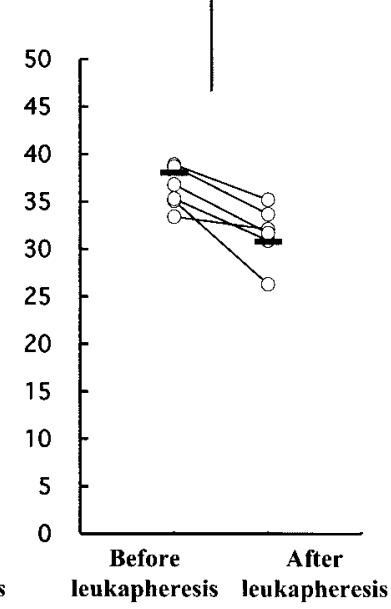

Modified procedure

Fig. 3. Avoidance of severe anemia with the modified procedure. The degree of anemia was significantly ameliorated with the modified procedure as compared to the unmodified one as assessed by the ratios of hemoglobin (A) and hematocrit levels (B) after versus before the leukapheresis. One monkey died of cardiac failure $(*, 292079)$ after the unmodified procedure. A: Hemoglobin levels. B: Hematocrit levels.

A

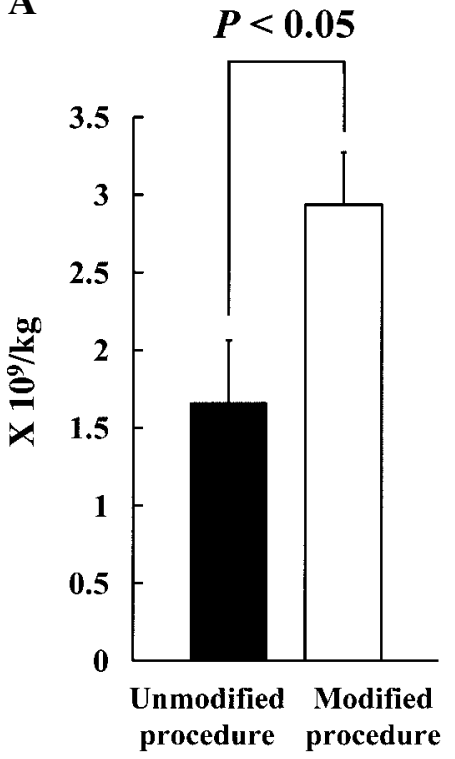

B

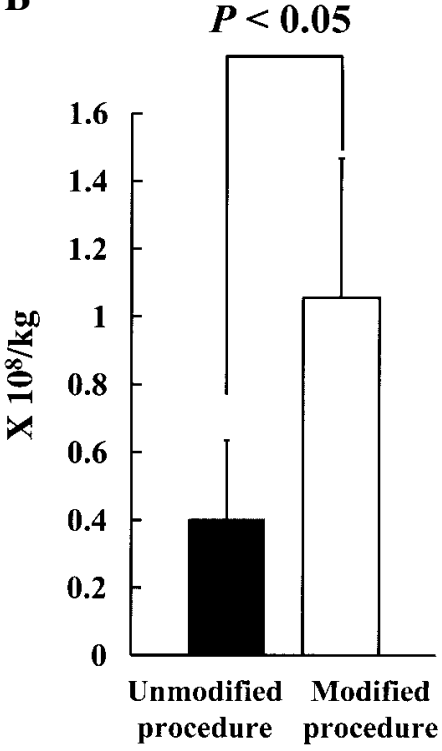

C

C $P<0.05$

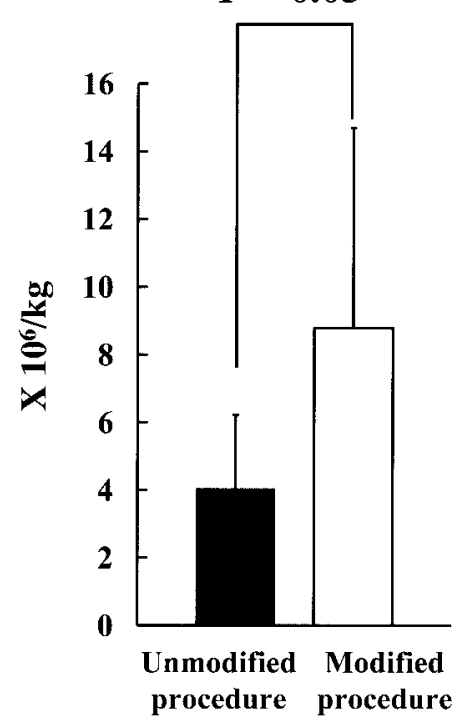

Fig. 4. Larger harvest of cells with the modified procedure. The numbers of harvested nuclear cells (A), mononuclear cells (B), and CD34+ cells $(\mathrm{C})$ were significantly increased with the modified procedure. A: Total nuclear cells. B: Mononuclear cells. C: CD34+ cells

of leukapheresis for adults $[10,13,25,28]$ and children $[1,8,15,31]$, only one very limited trial has been conducted on a human newborn baby [32]. To our knowledge, this paper is the first systematic documentation of leukapheresis for small primates.
One of the most serious complications in leukapheresis with small animal subjects is cardiac failure due to the relatively large amount of extracorporeal blood volume [10,32]. The main symptoms include hypotension and dyspnea, which sometimes result in 
death, e.g. animal 292079 (Table 2). To avoid this complication, the extracorporeal blood volume should be reduced as much as possible. No monkeys underwent cardiac failure after our modified procedure. There was, however, an age variation in the unmodified and modified procedure groups. The unmodified procedure group included higher age animals (6 and 7 years). Cynomolgus monkeys of these ages are young adults, and presumably they are more resistant to stress or invasion than monkeys of a juvenile age ( 3 years). Clearly, the age distribution of the groups, the higher age monkeys belonging to the modified procedure group, was not better than the present way.

Non-human primate models would be useful for preclinical studies of cell and gene therapies. We have previously reported the transplant of $\mathrm{CD} 34^{+}$stem cells into the ischemic myocardium in cynomolgus monkeys and found that the cardiac function was improved, indicating that further investigation is warranted for clinical application of $\mathrm{CD}_{3} 4^{+}$stem cell transplant to such disorder [34]. In other studies, we successfully transplanted gene-modified $\mathrm{CD} 34^{+}$stem cells into cynomolgus monkeys as a preclinical gene therapy $[11,30]$. In this way, our safe and efficient method for collecting peripheral blood stem cells should allow investigators to develop and test new therapies using stem cells in small non-human primates.

\section{Acknowledgments}

We are grateful to Masaaki Kimikawa and Kei Eguchi (Department of Surgery III, Tokyo Women's Medical University) for their helpful discussions. We thank Hyato Narita and Katsuhiko Komatsuzaki for their handling and care of the monkeys. We acknowledge Amgen's supply of SCF and Chugai's supply of GCSF. This study was supported by grants (KAKENHI, HAITEKU, JMS 21st Century COE Program, and Creation of Innovations) from the Ministry of Education, Culture, Sports, Science and Technology of Japan as well as grants (KAKENHI) from the Ministry of Health, Labour and Welfare of Japan.

\section{References}

1. Abe, T., Makimoto, A., Kawano, Y., Okamoto, Y., Kajiume, T., Nakagawa, R., Watanabe, H., Sato, J., Watanabe, T., Kuroda, Y., and Takaue, Y. 1998. Intra-apheresis recruitment of blood progenitor cells in children. Transfusion 38: 944-950.

2. Ageyama, N., Hanazono, Y., Shibata, H., Ohto, K., Ono, F., Nagashima, T., Ueda, Y., Donahue, R.E., Hasegawa, M., Ozawa, K., Yoshikawa, Y., and Terao, K. 2002. Safe and efficient methods of autologous hematopoietic stem cell transplantation for biomedical research in cynomolgus monkeys. Comp. Med. 52: 445-451.

3. Ageyama, N., Kimikawa, M., Eguchi, K., Ono, F., Shibata, H., Yoshikawa, Y., and Terao, K. 2003. Modification of the leukapheresis procedure for use in rhesus monkeys (Macaca mulata) J. Clin. Apher. 18: 26-31.

4. Ageyama, N., Shibata, H., Narita, H., Hanari, K., Kohno, A., Ono, F., Yoshikawa, Y., and Terao, K. 2001. Specific gravity of whole blood in cynomolgus monkeys (Macaca fascicularis), squirrel monkeys (Saimiri sciureus) and tamarins (Saguinus labiatus) and total blood volume in cynomolgus monkeys. Contemp. Top. Lab. Anim. Sci. 40: $33-35$.

5. Berenson, R.J., Bensinger, W.I., Hill, R.S., Andrews, R.G., Garcia-Lopez, J., Kalamasz, D.F., Still, B.J., Spitzer, G., Buckner, C.D., Bernstein, I.D., and Thomas, E.D. 1991. Engraftment after infusion of $\mathrm{CD} 4^{+}$marrow cells in patients with breast cancer or nueroblastoma. Blood 77: 1717-1722.

6. Biesma, D.H., Kraaijenhagen, R.J., Dalmulder, J., Marx, J.J., and van de Wiel, A. 1994. Recombinant human erythropoietin in autologous blood donors: a dose-finding study. Br. J. Haematol. 86: 30-35.

7. Blanchette, V.S., McCombie, N.E., and Rock, G. 1985. Factors that influence lymphocyte yields in lymphocytapheresis. Transfusion 25: 242-245.

8. Diaz, M.A., Alegre, A., Benito, A., Villa, M., and Madero, L. 1998. Peripheral blood progenitor cell collection by largevolume leukapheresis in low-weight children. $J$. Hematother. 7: 63-68.

9. Donahue, R.E., Kirby, M.R., Metzger, M.E., Agricola, B.A., Sellers, S.E., and Cullis, H.M. 1996. Peripheral blood CD $34+$ cells differ from bone marrow CD34+ cells in Thy1 expression and cell cycle status in nonhuman primates mobilized or not mobilized with granulocyte colonystimulating factor and/or stem cell factor. Blood 87: 1644-1653.

10. Goldberg, S.L., Mangan, K.F., Klumpp, T.R., Macdonald, J.S., Thomas, C., Mullaney, M.T., and Au, F.C. 1995. Complications of peripheral blood stem cell harvesting: review of 554 PBSC leukapheresis. J. Hematother. 4: 8590.

11. Hanazono, Y., Nagashima, T., Takatoku, M., Shibata, H., Ageyama, N., Asano, T., Ueda, Y., Dunbar, C.E., Kume, A., Terao, K., Hasegawa, M., and Ozawa, K. 2002. In vivo selective expansion of gene-modified hematopoietic cells in a nonhuman primate model. Gene Ther. 9: 1055-1064.

12. Honjo, S. 1985. The Japanese Tsukuba Primate Center for Medical Science (TPC): an outline. J. Med. Primatol. 14: $75-89$.

13. Jeanne, M., Bouzgarrou, R., Lafarge, X., Fizet, D., Dazey, B., Vezon, G., and Ivanovic, Z. 2003. Comparison of CD34+ 
cell collection on the CS-3000+ and Amicus blood cell separators. Transfusion 43: 1423-1427.

14. Kajiume, T., Kawano, Y., Takaue, Y., Abe, T., Okamoto, Y., Makimoto, A., Watanabe, T., Sato, J., Yokobayashi, A., and Kuroda, Y. 1998. Continuous monitoring of hematocrit values during apheresis for allogeneic peripheral blood stem cell collection. J. Hematother. 7: 493-497.

15. Kanold, J., Halle, P., Rapatel, C., Berger, M., Gembara, P., de Lumley, L., Vannier, J.P., Lutz, P., Plantaz, D., Malpuech, G., and Demeocq, F. 1998. Safe and efficient peripheral blood stem cell collection in the smallest of children. Ther. Apher. 2: 49-57.

16. Kessinger, A., Armitage, J.O., Smith, D.M., Landmark, J.D., Bierman, P.J., and Weisenburger, D.D. 1989. Highdose therapy and autologous peripheral blood stem cell transplantation for patients with lymphoma. Blood 74: $1260-1265$.

17. Korbling, M., Przepiorka, D., Huh, Y.O., Engel, H., van Besien, K., Giralt, S., Andersson, B., Kleine, H.D., Seong, D., Deisseroth, A.B., Andreeff, M., and Champlin, R. 1995. Allogeneic blood stem cell transplantation for refractory leukemia and lymphoma: potential advantage of blood over marrow allografts. Blood 85: 1659-1665.

18. Nash, K., Chang, Q., Watts, A., Treter, S., Oravec, G., Ferrara, V., Buhler, L., Basker, M., Gojo, S., Sachs, D.H., White-Scharf, M., Down, J.D., and Cooper, D.K. 1999. Peripheral blood progenitor cell mobilization and leukapheresis in pigs. Lab. Anim. Sci. 49: 645-649.

19. Negrin, R.S., Atkinson, K., Leemhuis, T., Hanania, E., Juttner, C., Tierney, K., Hu, W.W., Johnston, L.J., Shizurn, J.A., Stockerl-Goldstein, K.E., Blume, K.G., Weisman, I.L., Bower, S., Baynes, R., Dansey, R., Karanes, C., Peters, W., and Klein, J. 2000. Transplantation of highly purified CD34+Thy-1+ hematopoietic stem cells in patients with metastatic breast cancer. Biol. Blood Marrow Transplant. 6: 262-271.

20. Norol, F., Merlet, P., Isnard, R., Sebillon, P., Bonnet, N., Cailliot, C., Carrion, C., Ribeiro, M., Charlotte, F., Pradeau, P., Mayol, J.F., Peinnequin, A., Drouet, M., Safsafi, K., Vernant, J.P., and Herodin, F. 2003. Influence of mobilized stem cells on myocardial infarct repair in a nonhuman primate model. Blood 102: 4361-4368.

21. Primate Society of Japan. 1986. Guiding Principles for Animal Experiments Using Nonhuman Primates. Primate Res. 2: 111-113.

22. Rosenfeld, C.S. 1993. A strategy for processing of peripheral blood stem cells utilizing the small volume collection chamber and cryopreservation without a rate controller using pentastarch. J. Hematother. 2: 525-528.

23. Rowley, S.D., Prather, K., Bui, K.T., Appel, M., Felt, T., and Bensinger, W.I. 1999. Collection of peripheral blood progenitor cells with an automated leukapheresis system. Transfusion 39: 1200-1206.

24. Schmitz, N., Dreger, P., Suttorp, M., Rohwedder, E.B., Haferlach, T., Loffler, H., Hunter, A., and Russell, N.H. 1995. Primary transplantation of allogeneic peripheral blood progenitor cells mobilized by filgrastim (granulocyte colony-stimulating factor). Blood 85: 1666-1672.

25. Schwella, N., Movassaghi, K., Scheding, S., Ahrens, N., and Salama, A. 2003. Comparison of two leukapheresis programs for computerized collection of blood progenitor cells on a new cell separator. Transfusion 43: 58-64.

26. Shibata, H., Hanazono, Y., Ageyama, N., Nagashima, T., Ueda, Y., Hasegawa, M., Ozawa, K., Yoshikawa, Y., and Terao, K. 2003. Collection and analysis of hematopoietic progenitor cells from cynomolgus macaques (Macaca fascicularis): assessment of cross-reacting monoclonal antibodies. Am. J. Primatol. 61: 3-12.

27. Snyder, E.L., Baril, L., Cooper, D.L., Min, K., Mechanic, S., Stoddart, L., Burtness, B., Seagraves, P., Debelak, J., Gudino, M., and McCullough, J. 2000. In vitro collection and posttransfusion engraftment characteristics of MNCs obtained by using a new separator for autologous PBPC transplantation. Transfusion 40: 961-967.

28. Sohn, S.K., Kim, J.G., Chae, Y.S., Kim, D.H., Lee, N.Y., Suh, J.S., and Lee, K.B. 2003. Large-volume leukapheresis using femoral venous access for harvesting peripheral blood stem cells with the Fenwal CS 3000 Plus from normal healthy donors: predictors of $\mathrm{CD} 34^{+}$cell yield and collection efficiency. J. Clin. Apher. 18: 10-15.

29. Stamm, C., Westphal, B., Kleine, H.D., Petzsch, M., Kittner, C., Klinge, H., Schumichen, C., Nienaber, C.A., Freund, M., and Steinhoff, G. 2003. Autologous bone-marrow stemcell transplantation for myocardial regeneration. Lancet 361 : $45-46$.

30. Ueda, K., Hanazono, Y., Shibata, H., Ageyama, N., Ueda, Y., Ogata, S., Tabata, T., Nagashima, T., Takatoku, M. Kume, A., Ikehara, S., Taniwaki, M., Terao, K., Hasegawa, M., and Ozawa, K. 2004. High-level in vivo gene marking after gene-modified autologous hematopoietic stem cell transplantation without marrow conditioning in nonhuman primates. Mol. Ther. 10: 469-477.

31. Witt, V., Fischmeister, G., Scharner, D., Printz, D., Pottschger, U., Fritsch, G., and Gadner, H. 2001. Collection efficiencies of MNC subpopulations during autologous $\mathrm{CD} 34^{+}$peripheral blood progenitor cell (PBPC) harvests in small children and adolescents. J. Clin. Apher. 16: 161168.

32. Woloskie, S., Armelagos, H., Meade, J.M., and Haas, D. 2001. Leukodepletion for acute lymphocytic leukemia in a three-week-old infant. J. Clin. Apher. 16: 31-32.

33. Yoshino, N., Ami, Y., Terao, K., Tashiro, F., and Honda, M. 2000. Upgrading of flow cytometric analysis for absolute counts, cytokines and other antigenic molecules of cynomolgus monkeys (Macaca fascicularis) by using antihuman cross-reactive antibodies. Exp. Anim. 49: 97-110.

34. Yoshioka, T., Ageyama, N., Shibata, H., Yasu, T., Misawa, Y., Takeuchi, K., Matsui, K., Yamamoto, K., Terao, K., Shimada, K., Ikeda, U., Ozawa, K., and Hanazono, Y. 2005. Repair of infarcted myocardium mediated by transplanted bone marrow-derived $\mathrm{CD}^{3} 4^{+}$stem cells in a nonhuman primate model. Stem Cells 23: 355-364. 